\title{
Mass Spectrometry of Chlorophylls from Phototrophic Prokaryotes
}

\author{
Ruth L. Airs
}

Plymouth Marine Laboratory, Prospect Place, Plymouth, Devon. PL1 3DH. United Kingdom.

\begin{abstract}
Phototrophic prokaryotes inhabit a diverse array of environments on our planet and also contain a wide range of chlorophylls and bacteriochlorophylls, encompassing both chlorin and bacteriochorin structures. Mass spectrometry, particularly coupled with liquid chromatography and used in conjunction with soft ionization techniques, has been pivotal in the assignment of closely related chlorophyll and bacteriochlorophyll structures from these organisms. This review considers the ecological niches of the phototrophic prokaryotes, together with the mass spectrometric study of their chlorophyll and bacteriochlorophyll pigments.
\end{abstract}

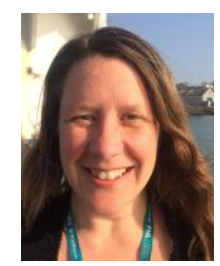

Keywords: bacteriochlorophyll, chlorophyll $f$, chlorophyll $d$, fragmentation, liquid chromatography/mass spectrometry, photosynthetic bacteria.

\section{INTRODUCTION}

Phototrophic prokaryotes are bacteria or archaea that obtain energy from light, and comprise a diverse array of microorganisms inhabiting a wide range of ecological niches from oxygenic, oceanic gyres (high light, low nutrients, oxygenated) to the monimolimnion of meromictic lakes (extremely low light intensity, sulphidic, anoxic). The Chlorophototrophic bacteria that use bacteriochlorophylls and/or chlorophylls to produce energy for growth are currently known to occur in seven phyla: Cyanobacteria, Proteobacteria, Chlorobi, Chloroflexi, Firmicutes, Acidobacteria, and Gemmatimonadetes. The chlorophylls of
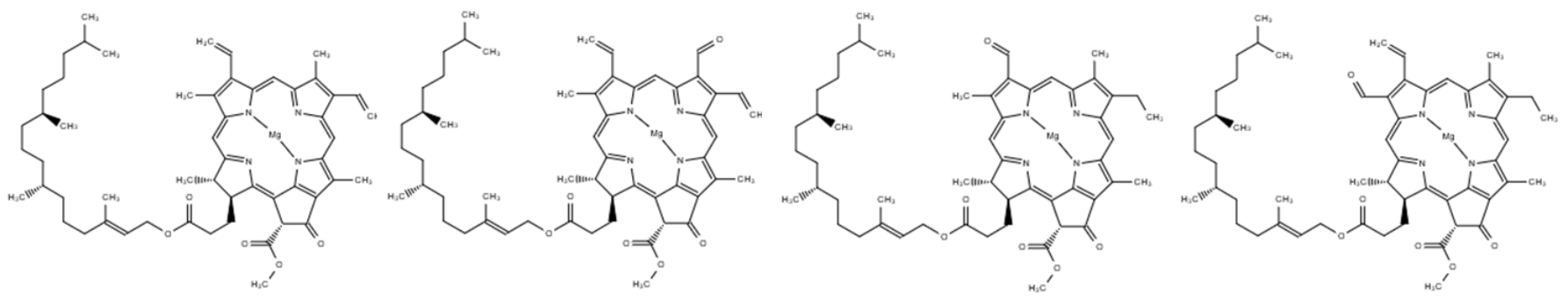

divinyl chlorophyll a

divinyl chlorophyll $b$ the phototrophic prokaryotes, in combination with the specialist design of the photosynthetic apparatus, have evolved to suit the ecological niche of the organism. Thus, a complex array of chlorophylls and bacteriochlorophylls from prokaryotic cells exist and have been studied using mass spectrometry, including those from cultures, natural populations, their diagenetic counterparts in sediments, and structures biosynthesized by genetic mutants. In this review, the ecological niche of each organism type will be considered in turn, together with the mass spectrometric analysis of their key chlorophylls/bacteriochlorophylls. chlorophyll $f$
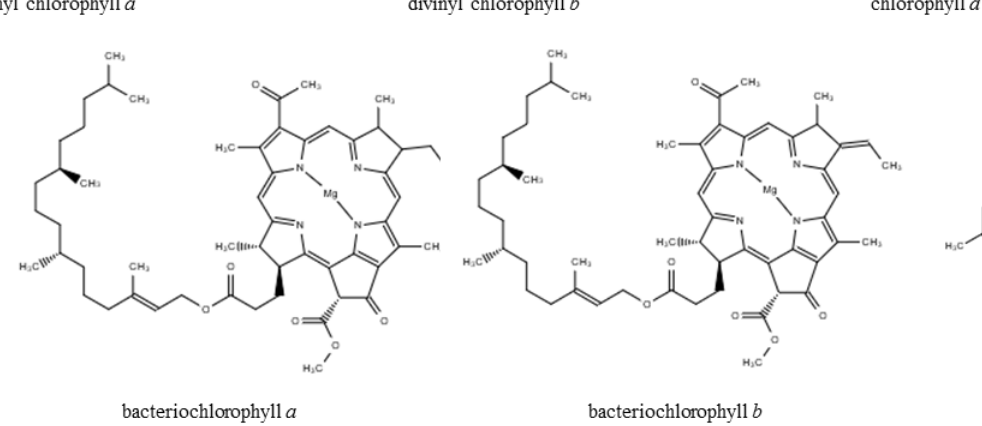

bacteriochlorophyll $b$
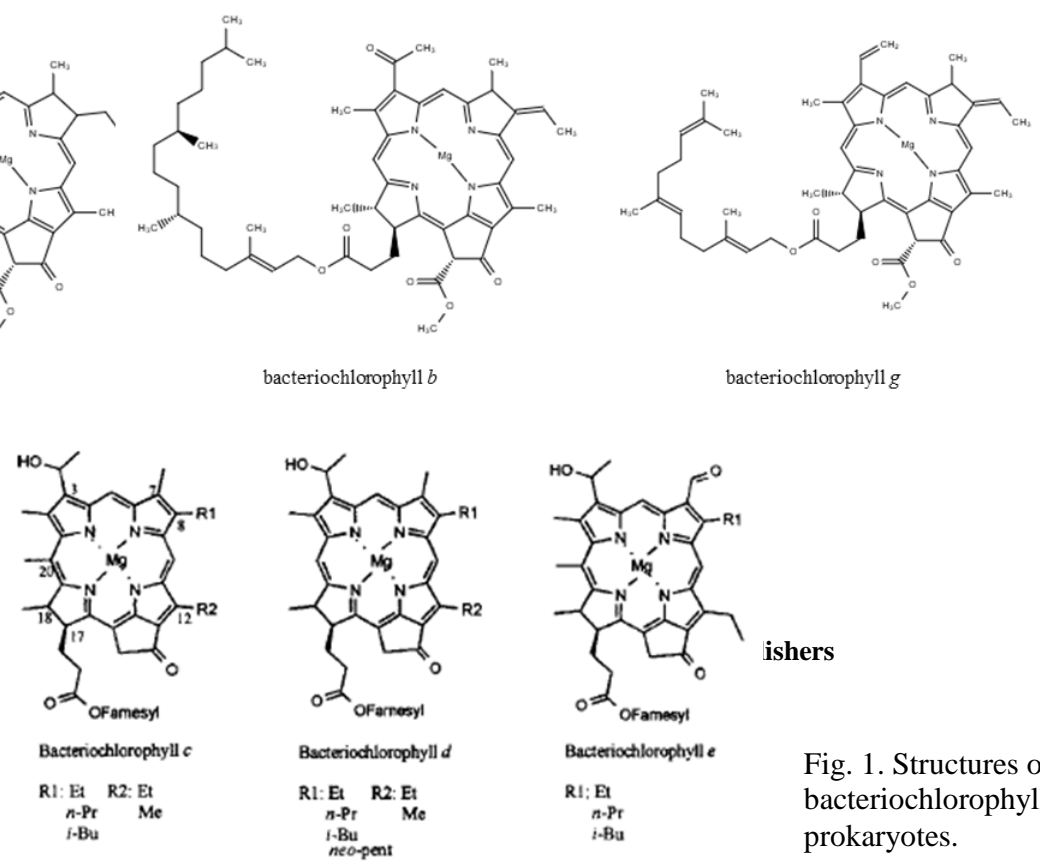

ishers

Fig. 1. Structures of the chlorophylls and bacteriochlorophylls of phototrophic prokaryotes. 


\section{CYANOBACTERIA}

The cyanobacteria are an extremely diverse taxonomic group and are photosynthetic prokaryotes that carry out oxygen evolving photosynthesis. Most cyanobacteria use chlorophyll $a$ as their main light harvesting chlorophyll. Mass spectrometry studies of chlorophyll $a$ are addressed in [1] (this issue), and cyanobacteria that utilise chlorophyll $a$ as a main photosynthetic pigment will not be considered here. Several genera of cyanobacteria however contain different chlorophylls as their main light harvesting chlorophyll, including divinyl chlorophyll $a$ (Prochlorococcus) and chlorophyll $d$ (Acaryochloris) (for structures, see Fig. 1). Furthermore, several genera have been found to produce far-red absorbing chlorophylls under conditions where UV/vis is depleted and far red light is available [2]. These cyanobacteria, and the mass spectrometric studies of their chlorophylls, will be reviewed below.

\subsection{Prochlorococcus}

Prochlorococcus is a marine cyanobacterium abundant in oligotrophic waters [3] that contains divinyl chlorophylls $a$ and $b$ [4]. Prochlorococcus forms different ecotypes which vary in their proportions of divinyl chlorophyll $a$ and $\mathrm{b}$, and their adaptation to different light intensities [5,6]. Before the availability of the soft ionization techniques atmospheric pressure chemical ionization (APCI) and electrospray ionization (ESI), divinyl chlorophylls $a$ and $b$ were studied by fast atom bombardment mass spectrometry, during which a high velocity beam of an inet gas (eg. Xenon) is directed onto the sample within a matrix (eg. Glycerol, or chloroform/trigol for chlorophylls [7], causing desorption of protonated or deprotonated molecules from the sample. FAB-MS yielded both radical cations and protonated molecules for divinyl chlorophyll $a$ at $\mathrm{m} / \mathrm{z} 890$ and 891, respectively [7], and a radical cation at $\mathrm{m} / \mathrm{z}, 904$ for divinyl chlorophyll $b$ [8]. For divinyl chlorophyll $a$, a further peak in the FAB-MS spectrum was observed at $\mathrm{m} / z$ 613, corresponding to loss of the phytyl side chain from the protonated molecule [7]. Recently, a strain of Alexandrium ostenfeldii, a eukaryotic dinoflagellate was found to produce divinyl chlorophyll $a$ in addition to chlorophyll $a$ [9] probably due to a genetic mutation. The growth rate, and fitness was reduced compared to the chlorophyll $a$ containing strain, indicating the strain would be a minor population in a dinoflagellate assemblage, so therefore, this first report of divinyl chlorophyll $a$ outside of the cyanobacterial genus Prochlorococcus is unlikely to affect the robustness of divinyl chlorophyll $a$ as a marker for Prochlorococcus. The application of high resolution positive ion electrospray ionsation (ESI)-MS allowed a more thorough examination of the MS properties of this chlorophyll than FAB-MS. High resolution ESI-MS spectra revealed all ions appeared two daltons lower than those observed for chlorophyll $a$ (reviewed by [10]), consistent with an additional double bond compared to chlorophyll $a$. The high mass range exhibited sodiated $(m / z, 913.5084)$ and

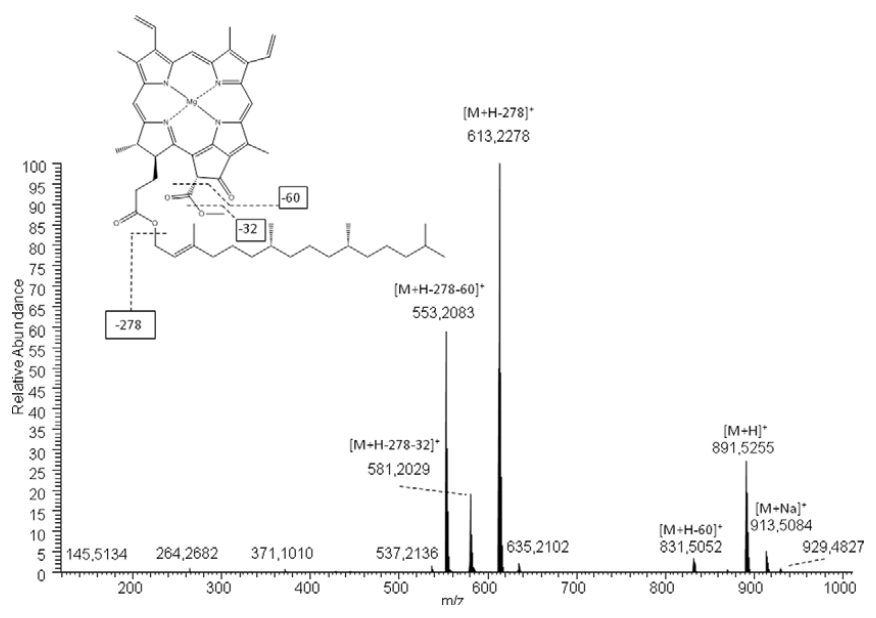

Fig. 2. High resolution ESI-MS of divinyl chlorophyll $a$. Reproduced from [9] .

protonated $(\mathrm{m} / \mathrm{z}$ 891.5255) molecules consistent with the monoisotopic mass of divinyl chlorophyll $a$ (Fig. 2). Main fragment ions corresponded to loss of the phytyl chain $(\mathrm{m} / \mathrm{z}$ 613.2301), and from combined losses of the phytyl chain and methanol (32 Da), from the carbomethoxy substituent at C$13^{2}$ (581.2029; Fig. 2), and the phytyl chain and the entire carbomethoxy substituent (553.2083; Fig. 2; [9]). The loss of $60 \mathrm{Da}$ from the carbomethoxy substituent is also observed in the high mass region at $\mathrm{m} / \mathrm{z}$ 831.5052, occurring directly from the protonated molecule (Fig. 2). Notably, analysis of divinyl chlorophyll $a$ and $b$ using ESI-MS can also result in formation of radical cations during ionization and MS/MS as observed by [11].

\subsection{Acaryochloris}


Acaryochloris marina is a unique cyanobacterium that utilizes chlorophyll $d$ as its principle light harvesting pigment instead of chlorophyll $a[12,13]$. The habitats of Acaryochloris marina include the underside of both red algae [14], and didemnid ascidians, which comprise habitats enriched in near-IR compared to UV/vis, providing a niche for cyanobacteria containing chlorophyll $d$ [15]. Since the discovery of Acaryochloris spp. it has been found to be widely distributed in both aquatic and terrestrial systems, including a eutrophic hypersaline lake [16], high altitude lakes [17], temperate freshwater and saline lakes [18], terrestrial epilithic and endolithic biofilms $[19,20,21]$ and stromatolites [22]. Furthermore, the occurrence of chlorophyll $d$ and its degradation products in sediments has been reported to be widespread [18], although substantial conversion of pyrophaeophorbide $a$ into pyrophaeophorbide $d$ has been reported under mild conditions [23]. Similarly, conversion of chlorophyll $a$ into chlorophyll $d$ has been achieved using a thiol under acidic conditions [24], and conversion of vinyl to formyl groups in naturally occurring
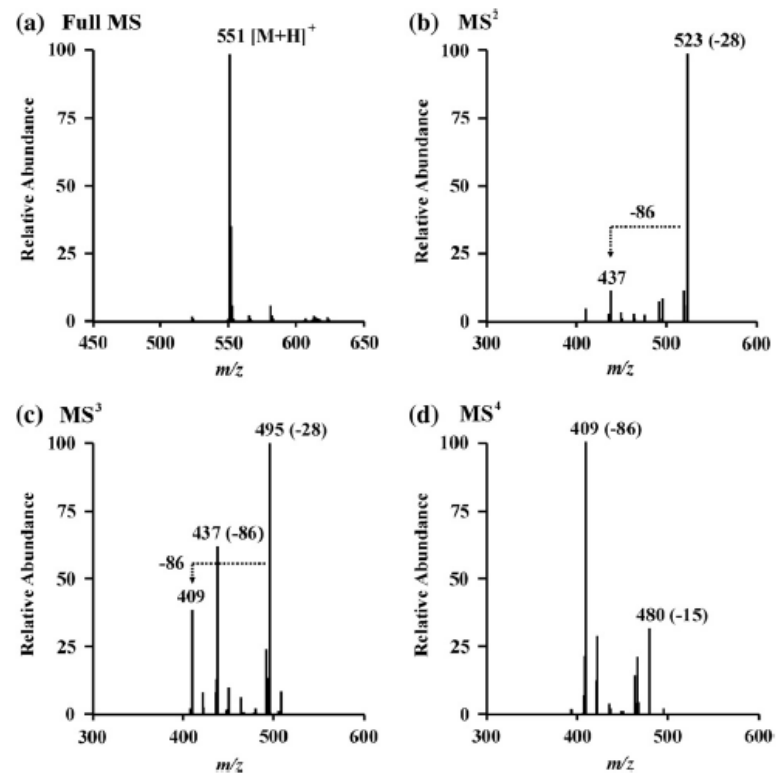

Fig. 3. APCI multistage tandem mass spectra of pyrophaeophorbide $d$ (a) full MS, (b) $\mathrm{MS}^{2}$, (c) $\mathrm{MS}^{3}$, (d) $\mathrm{MS}^{4}$. In each case the most abundant ion was selected as the precursor for the next spectrum. Reproduced from [23].

chlorophylls under mild conditions [25]. Thus until similar reactions in natural environments are well understood, the apparent widespread distribution of chlorophyll $d$-type structures in sediments should be interpreted with caution. The structure of chlorophyll $d$ differs from that of chlorophyll $a$ in the presence of a formyl group at position C-3 (Fig. 1), where chlorophyll $a$ exhibits a vinyl group. Under liquid chromatography (LC)-APCI-MS/MS with post column addition of formic acid [26], chlorophyll $d$ gave rise to ions at $\mathrm{m} / \mathrm{z} 895$ and $\mathrm{m} / \mathrm{z} 873$ corresponding to $[\mathrm{M}+\mathrm{H}]^{+}$and $\mathrm{M}+3 \mathrm{H}-\mathrm{Mg}]^{+}$respectively $[27,28]$. Isolation and fragmentation of the ion at $m / z, 873$ in the ion trap gave rise to major ions at $m / z 595$ and $m / z 535$ in $\mathrm{MS}^{2}$, arising from loss of the phytyl chain from $\mathrm{C}-17^{3}$, and loss of the phytyl chain in addition to the $\mathrm{CO}_{2} \mathrm{Me}$ group from $\mathrm{C}-13^{2}$, respectively $[27,28]$. Further fragmentations can be discerned from the APCI multistage tandem mass spectra of methyl-pyrophaeophorbide $d$ [23] (Fig. 3), as this structure lacks a phtyl chain at $\mathrm{C}-17^{3}$ and carbomethoxy substituent at $\mathrm{C}-13^{2}$. The protonated molecule of methylpyrophaeophorbide $d$ (Fig. 3) occurred at $\mathrm{m} / \mathrm{z} 551,2 \mathrm{~m} / \mathrm{z}$ units more than methyl-pyrophaeophorbide $a\left([\mathrm{M}+\mathrm{H}]^{+}=m / z\right.$ 549). The $\mathrm{MS}^{2}$ spectrum of $\mathrm{m} / \mathrm{z} 551$ gave rise to prominent ions at $\mathrm{m} / \mathrm{z} 523$ and 437, corresponding to loss of $\mathrm{CO}$ from $\mathrm{C}-13^{1}$ and its loss in combination with the entire C-17 methylpropionate ester accompanied by hydrogen transfer to the charge retaining macrocycle, respectively (Fig. 3; [23]). The occurrence of the same losses in the $\mathrm{MS}^{2}$ spectrum of methyl-phaeophorbide $a$, lends support to the assignments [29]. The relative abundance of $\mathrm{m} / \mathrm{z} 523$ is significantly higher in the $\mathrm{MS}^{2}$ spectrum of methyl-pyrophaeophorbide $d$, than that of the analogous ion in the $\mathrm{MS}^{2}$ spectrum of methyl-pyrophaeophorbide $a[23,29]$ indicating an increased probability of losing $28 \mathrm{Da}$ to form the base peak at $\mathrm{m} / \mathrm{z} 523$ i.e. more than one source of $m / z, 28$ from the macrocycle of methyl-pyrophaeophorbide $d$. Furthermore, isolation and fragmentation of $\mathrm{m} / \mathrm{z}, 523$ gave rise to a second loss of $28 \mathrm{Da}$, forming a base peak at $\mathrm{m} / \mathrm{z}, 495$ in $\mathrm{MS}^{3}$, and attributed to a second loss of $\mathrm{CO}$, formally arising from the formyl substituent at position C-3 (Fig. 3; [23]). A second loss of 28 $\mathrm{Da}$ is not observed in the $\mathrm{MS}^{\mathrm{n}}$ spectra of methylpyrophaeophorbide $a$ [29]. Two successive losses of $28 \mathrm{Da}$ are, however, observed in the $\mathrm{MS}^{\mathrm{n}}$ spectra of methylpyrophaeophorbide $b$, which exhibits a formyl group at position C-7 [30]. Two successive losses of $28 \mathrm{Da}$ are also observed in the $\mathrm{MS}^{\mathrm{n}}$ spectra of bacteriochlorophyll $e$ [31], which also exhibits a formyl group at position C-7. Thus, two successive losses of $28 \mathrm{Da}$ during $\mathrm{MS}^{\mathrm{n}}$ studies is indicative of formyl-substituted chlorins.

\subsection{Chlorophyll f-producing cyanobacteria}

In addition to Acaryochloris, other aquatic and terrestrial cyanobacteria occur in environments that receive light diminished in UV/vis, but replete in near-IR because of shading by organisms above them $e g$. in benthic mat or soil communities. Some cyanobacteria are able to use far red light for photosynthesis, by utilizing chlorophyll $f$ [32] and chlorophyll $d$ in addition to chlorophyll $a$ and undergoing an extensive remodeling of their photosynthetic apparatus [33]. To date, thirteen strains of sequenced cyanobacteria have been shown to contain the gene cluster necessary for growth in far red light [33], and five diverse strains, including representatives from Synechecoccus sp. and Chlorogloeopsis $s p$. have been shown experimentally to exhibit far red light acclimation [2].

The near-IR absorbing chlorophyll $f$ [32] was isolated from the filamentous cyanobacterium Halomicronema hongdechloris [34], and has since been discovered in cyanobacteria from natural habitats including a Japanese lake [35], a dense cavernous biofilm [36], beachrock biofilms 
[37] and a culture of the cyanobacterium Chlorogloeopsis fritschii grown under natural and near-IR light [27]. Under soft ionisation conditions, chlorophyll $f$ produces a protonated molecule at $\mathrm{m} / \mathrm{z}$ 907, isobaric with that of chlorophyll $b$ under both APCI $[27,28]$ and ESI $[33,38]$, whereas matrix assisted laser desorption ionization (MALDI) yielded $\mathbf{M}^{+}$[32]. Upon fragmentation, chlorophyll $f$ gives rise to an $\mathrm{MS}^{2}$ spectrum typical of a formyl substituted chlorophyll macrocycle [31], comprising an ion at $\mathrm{m} / \mathrm{z} 879$ corresponding to loss of $28 \mathrm{Da}$ from $[\mathrm{M}+\mathrm{H}]^{+}$. The base peak in $\mathrm{MS}^{2}$ corresponded to an ion at $\mathrm{m} / z$ 629, arising from the loss of the phytyl chain [27, 28, 32, 33], as commonly seen for phytol-esterified chlorophylls [10]. As $[\mathrm{M}+\mathrm{H}]^{+}$of chlorophyll $f$ is isobaric with that of chlorophyll $b$, and the fragmentations observed under $\mathrm{MS}^{\mathrm{n}}$ are typical of those of formyl substituted chlorophylls, LC/MS in combination with $\mathrm{UV} / \mathrm{vis}$ detection is necessary to distinguish chlorophyll $f$ and chlorophyll $b$.

\section{GREEN BACTERIA}

The green bacteria occur within three phyla: the green sulphur bacteria of the phylum Chlorobi, the filamentous anoxygenic phototrophs of the phylum Chloroflexi and the more recently discovered Candidatus Chloracidobacterium thermophilum [39] of the phylum Acidobacter. Chlorobiaceae e.g. Chlorobium limicola are strict anaerobes that grow by utilizing sulphide or thiosulphate as an electron donor for photosynthesis [40]. Chloroflexaceae e.g. Chloroflexus aurantiacus are facultative anaerobes which can utilize carbon compounds as electron donors for growth. The green bacteria contain bacteriochlorophylls $c, d$, or $e$ as their main photosynthetic pigments, and locate their pigments inside similar structures (chlorosomes) within the cell, but they use different types of electron transfer pathways.

Light available to organisms that require anoxic environments is usually severely limited due to attenuation with depth either, for example, through a water column or a microbial mat. Chlorobiaceae have been shown to biosynthesize higher proportions of bacteriochlorophylls with extended side chains in response to low light conditions, allowing them to produce longer wavelength absorbing aggregates in their chlorosomes which may be advantageous either in light absorption or to effect more efficient transfer of energy to the reaction centre [41, 42]. Bacteriochlorophylls $c, d$ and $e$ are dihydroporphyrins that lack the $\mathrm{C}-13^{2}$ carbomethoxy group of chlorophylls and bacteriochlorophylls $a$ and $b$, and hence their $\mathrm{MS}^{\mathrm{n}}$ spectra lack ions arising from fragmentation of this group [10]. All three of the bacteriochlorophylls of Chlorobiaceae possess a hydroxyethyl substituent at position C-3 (Fig. 1). Additionally, the major esterifying alcohol at position $\mathrm{C}-17^{3}$ is farnesol, although a number of other esterifying alcohols have been reported [43-49]. Bacteriochlorophyll $e$ has an aldehyde at position C-7, where bacteriochlorophylls $c$ and $d$ exhibit a methyl group (Fig. 1). Bacteriochlorophyll $d$ lacks the methyl substituent present in bacteriochlorophylls $c$ and $e$ at position C-20. Bacteriochlorophylls $c, d$ and $e$ exist as series of homologues that differ in the degree of alkylation at positions C-8 and/or C-12 (Fig. 1). Within Chlorobiaceae, a series of secondary homologues can occur, which differ by both the degree of alkylation at C-8 and/or C-12, and the esterifying alcohol at position $\mathrm{C}-17^{3}$. The bacteriochlorophylls of Chloroflexaceae exist as series of structures that usually have a single alkylation pattern of [Et, $\mathrm{Me}]$ at $\mathrm{C}-8$ and $\mathrm{C}-12$ and differ in the nature of the esterifying alcohol at position $\mathrm{C}-17^{3}$ [50-52], although variation of both the esterifying alcohol and the degree of alkylation at C-8 and C-12 has been observed in some strains [52]. An enrichment culture of Candidatus Chloracidobacterium thermophilum was found to contain a complex pattern of bacteriochlorophyll $c$ homologues consistent with both methylation at C-8 and/or C-12, and a variety of alcohols esterified at position $\mathrm{C}-17^{3}$ [39]. The diversity of structures exhibited by the bacteriochlorophylls, and the differences in the macrocycle substituents compared to those of chlorophylls $a$ and $b$, make them excellent candidates for studies by mass spectrometry.

Some elements of bacteriochlorophyll fragmentation during mass spectrometry studies have been reviewed previously [10]. Thus, the salient points only will be considered here. The hydroxyethyl group at position C-3 of bacteriochlorophylls $c, d$ and $e$ has been observed to fragment both by dehydration, producing $[\mathrm{M}+\mathrm{H}-18]^{+}$which can be observed in the full mass spectrum, as well as a minor ion in $\mathrm{MS}^{2}[31,46,53,54]$, and by the loss of $44 \mathrm{Da}$, assigned as the loss of the entire substituent with proton transfer back to the macrocycle $[31,55,56]$. The absence of the C-20 methyl group i.e. the structural difference between bacteriochlorophylls $c$ and $d$, influences the fragmentation of the C-3 hydroxyethyl group, in that the ion arising from a dehydration forms the base peak in $\mathrm{MS}^{2}$ of bacteriochlorophylls $c$ and $e$, and the ion arising from the loss of the whole C-3 substituent with $\mathrm{H}$-transfer back to the macrocycle forms the base peak in the $\mathrm{MS}^{2}$ spectrum of bacteriochlorophyll $d[31,56]$.

Like phytol, the isoprenoid esterifying alcohol of the bacteriochlorophylls, farnesol, fragments from the $\mathrm{C}-17^{3}$ position under MS/MS conditions to give the base peak in the $\mathrm{MS}^{2}$ spectrum, resulting from a loss of $204 \mathrm{Da}$ from $[\mathrm{M}+\mathrm{H}]^{+}[31,46,47,49,53,54,57,58]$. Similarly, the isoprenoid esterifying alcohol geranyl geraniol cleaves from $\mathrm{C}-17^{3}$ to give a base peak in the $\mathrm{MS}^{2}$ spectrum via loss of $272 \mathrm{Da}$ from $[\mathrm{M}+\mathrm{H}]^{+}[46,47,49,52,59]$. Notably, esterifying alcohols that obtain no stabilization energy on fragmentation via conjugation of double bonds, such as saturated straight and branched chain alcohols, do not cleave to give base peak ions in $\mathrm{MS}^{2}$. Fragmentations arising from the esterifying alcohol can still be discerned, but the $\mathrm{MS}^{2}$ spectra are dominated by ions arising from expulsion of small molecules from the macrocycle $[31,58]$.

Fragmentations arising from cleavage of the alkyl substituents at positions C- 8 and C- 12 are rarely observed in $\mathrm{MS}^{\mathrm{n}}$ studies of the parent bacteriochlorophylls, due to the number of more facile cleavages that can occur from the macrocycle substituents $[31,47]$. The alkylation pattern at C8 and C-12 is often deduced from the mass of the protonated molecule and the elution order of the bacteriochlorophylls or determined by NMR [53, 54, 60]. In a few cases, the alkylation at positions $\mathrm{C}-8$ and $\mathrm{C}-12$ has been deduced by studying the $\mathrm{MS}^{\mathrm{n}}$ spectra of bacteriochlorophylls to a high stage of $\mathrm{MS}^{\mathrm{n}}\left(\mathrm{MS}^{6}\right.$ or $\mathrm{MS}^{7} ;[31,47]$. Studies of porphyrins with extended alkyl substituents have shown them to 
fragment via $\beta$-cleavage, and those with ethyl and methyl sunstituents by $\alpha$-cleavage [61]. In both cases, the losses correspond to alkyl radicals. By studying the bacteriophaeophorbides, some of the functionality of the structure is reduced, namely the esterifying alcohol. This approach leads to loss of alkyl substituents as alkyl radicals, forming odd electron ions observed in $\mathrm{MS}^{5}$ and $\mathrm{MS}^{6}[31,56$, 62]. The methyl and ethyl substituents of the bacteriophaeophorbides were found to preferentially fragment $\alpha$ to the macrocycle, resulting in losses of 15 and $29 \mathrm{Da}$, respectively $[31,56,63]$. Conversely, n-propyl and ibutyl substituents of the bacteriophaeophorbides fragmented mainly by $\beta$-fragmentation, resulting in losses of 29 and 43 $\mathrm{Da}$, respectively, permitting assignment of the alkylation pattern at C-8 and C-12 [31, 56, 63].

\section{PURPLE BACTERIA}

The purple bacteria contain bacteriochlorophyll $a$ or $b$ and various carotenoids, and are subdivided into the families Chromatiaceae (purple sulphur bacteria), and Rhodospirillaceae (purple non-sulphur bacteria). Chromatiaceae e.g. Chromatium use sulphide as an electron donor in photosynthesis. Rhodospirillaceae e.g. Rhodobacter, Rhodospirillum and Rhodosuedomonas are a very diverse group. Many species are unable to use sulphide but can metabolise simple organic molecules for sources of reducing power [50]. Under APCI conditions, bacteriochlorophyll $a$, analysed as the bacteriophaeophytin due to post-column addition of acid [26] gives rise to a protonated molecule at $\mathrm{m} / \mathrm{z} 889$ [47]. Isolation of the ion at $\mathrm{m} / \mathrm{z} 889$ in the ion trap gives rise to a prominent ion at $\mathrm{m} / \mathrm{z}$ 611 in $\operatorname{MS}^{2}[46,47,59]$, corresponding to the loss of the phytyl chain, consistent with phytyl-esterified chlorins and bacteriochlorins. An ion observed in $\mathrm{MS}^{2}$ at $\mathrm{m} / \mathrm{z} 829$ corresponded to a loss of $60 \mathrm{Da}$, assigned to loss of the $\mathrm{C} 13^{2}$ carbomethoxy group with hydrogen abstraction from the charge retaining species $\left(\left[\mathrm{M}+\mathrm{H}-\mathrm{HCO}_{2} \mathrm{Me}\right]^{+}[59]\right.$. An ion at $\mathrm{m} / \mathrm{z} 847$ corresponding to a loss of $42 \mathrm{Da}$, was attributed to the loss of ethylketene from the C-3 position of the protonated molecule $\left(\left[\mathrm{M}+\mathrm{H}-\mathrm{CH}_{2} \mathrm{CO}\right]^{+}\right)[59]$. One species of purple bacteria, Rhodospirillum rubrum, has been found to use bacteriochlorophyll $a$ esterified with geranyl geraniol as the principal light harvesting pigment [64]. Under APCI conditions, bacteriophaeophytin $a$ esterified with geranyl geraniol gave rise to $[\mathrm{M}+\mathrm{H}]^{+}$at $\mathrm{m} / \mathrm{z} 883,6$ Da lower than that of bacteriophaeophytin $a$. Isolation and fragmentation in the ion trap gave rise to the same ions as bacteriophaeophytin $a$ at $\mathrm{m} / z, 611$ and 511, corresponding to the loss of the esterifying alcohol and the combined losses of the esterifying alcohol and the carbomethoxy substituent, indicating the structural difference between the bacteriophaeophyins $a$ was in the esterifying moiety. The mass loss of $272 \mathrm{Da}$ was consistent with geranyl geraniol. Notably, the high mass ions in $\mathrm{MS}^{2}$, occurred at $\mathrm{m} / \mathrm{z} 823$, and 841 , $6 \mathrm{Da}$ lower than those in the $\mathrm{MS}^{2}$ spectrum of bacteriophaeophytin a [59], providing further evidence of the esterifying alcohol as the site of the structural difference between the bacteriochlorophylls $a$.

\subsection{Other bacteriochlorophyll a-containing organisms}

The acidophilic bacterium Acidophilium rubrum has been reported to contain bacteriochlorophyll $a$ chelated with a central $\mathrm{Zn}$ atom [65] instead of $\mathrm{Mg}$ which chelates all other known photosynthetic chlorophylls and bacteriochlorophylls. The zinc atom is thought to offer improved resistance to demetallation under acidic conditions [66]. Under FAB-MS, the zinc-bacteriochlorophyll gave rise to a molecular on at $\mathrm{m} / \mathrm{z}$ 950.5, $40 \mathrm{Da}$ higher than that of the $\mathrm{Mg}$-chelated bacteriochlorophyll $a[65,66]$. An ion was also observed at $\mathrm{m} / \mathrm{z}$ 672, corresponding to a loss of $278 \mathrm{Da}$ from the molecular ion, attributed to the loss of phytyl $[65,66]$. Notably, under FAB-MS, the demetallated pigment gave rise to ions at $\mathrm{m} / \mathrm{z} 888$ and $\mathrm{m} / \mathrm{z} 610$, corresponding to those of bacteriophaeophytin $a$ [66], providing further evidence of the central chelated metal being the source of the mass difference between the bacteriochlorophyll structures.

A bacteriochlorophyll $a$-producing bacterium isolated from a freshwater lake in the western Gobi Desert was found to belong to the phylum Gemmatimonadetes [67], increasing the number of bacterial phyla which contain (bacterio)chlorophyll-based phototrophic species.

Aerobic anoxygenic phototrophic bacteria are a diverse group of bacteria that contain bacteriochlorophyll $a$ and require oxygen for both growth and bacteriochlorophyll $a$ biosynthesis, and can perform both phototrophy and heterotrophy [68]. They are reported to be widely distributed among marine plankton [69], and can comprise $11 \%$ of the total marine microbial community [70]. The aerobic anoxygenic phototrophic bacteria assemblages have been found to contain multiple, distantly related, photosynthetically active bacterial groups, including some unrelated to known and cultivated types [71]. The bacteriochlorophyll contect per cell of these bacteria is typically lower than other phototrophs [72].

\section{HELIOBACTERIA}

Heliobacteria are anoxygenic phototrophs that contain bacteriochlorophyll $g$ as their sole chlorophyll pigment [73, 74]. They are primarily soil residents, and are widely distributed in the soils of rice paddy fields. Bacteriochlorophyll $g$, like bacteriochlorophylls $a$ and $b$, has a bacteriochlorin $\pi$-system with single bonds at C-7-C-8 and C-17-C-18. Bacteriochlorophyll and bacteriophaeophytin $g$ have been analysed by heavy ion desorption mass spectrometry ${ }^{252}$ Cf-PDMS; [75], a time of flight technique in which molecular ions of the sample are created by impact of fission fragment ions resulting from the spontaneous fission of ${ }^{252} \mathrm{Cf}$. Under these conditions, average molecular ions at $\mathrm{m} / \mathrm{z} \quad 819$ and 797 were observed for bacteriochlorophyll and bacteriophaeophytin $g$, respectively [75], differing in $22 \mathrm{Da}$, the expected mass difference between magnesium-chelated and unchelated (bacterio)chlorophylls. Ions occurring at $[\mathrm{M}-204]^{+}$were also observed in the mass spectra, indicating bacteriochlorophyll $g$ was esterified by farnesol, and not geranyl geraniol as previously suggested [74]. Under FAB-MS conditions in a $m$-nitro-benzyl alcohol matrix, ions at $m / z, 818$ and 614 were observed for bacteriochlorophyll $g$, corresponding to $[\mathrm{M}-\mathrm{H}]$ and [M-H-204] [66]. These mass spectrometry techniques did not permit observation of a fragmentation from the carbomethoxy group at $\mathrm{C}-13^{2}$ of bacteriochlorophyll $g$.

\section{CONCLUSION}


Mass spectrometry has been valuable for studying the pigments of phototrophic prokaryotes, particularly where high structural variation occurs eg. homologues and pseudohomologues of bacteriochlorophylls $c, d$ and $e$, where the structural variation between homologues does not affect their $\mathrm{UV} /$ vis absorption spectra. The esterifying alcohol, presence or absence of a carbomethoxy substituent, chelating metal, macrocycle substituents and extent of alkylation at C-8 and C-12 are all discernable using $\mathrm{MS}^{\mathrm{n}}$ studies. Exploration of our natural environment continues to find previously uncharacterized photosynthetic prokaryotes utilizing subtle but significant modifications to the chlorophyll and bacteriochlorophyll structures in our current knowledge.

*Address correspondence to this author at the Plymouth Marine Laboratory, Prospect Place, Plymouth, PL13 2JP, United Kingdom; Tel/Fax: +44-1752633100; +44-1752-633101; E-mail: ruai@pml.ac.uk

\section{CONFLICT OF INTEREST}

The author confirms that this article has no conflict of interest.

\section{REFERENCES}

[1] Roca, M. Mass spectrometry of non-allomerized chlorophylls a and b derivatives from plants Current Organic Chemistry, 2017, this issue.

[2] Gan, F.; Shen, G.; Bryant, D.A. Occurrence of far-red light photoacclimcation (FaRLiP) in diverse cyanobacteria. Life, 2015, 5, 4-24; doi:10.3390/life5010004

[3] Partensky, F.; Hess, W.R.; Vaulot, D. Prochlorococcus, a marine photosynthetic prokaryote of global significance. Microbiology and Molecular Biology Reviews, 1999, 63, 106-127.

[4] Chisholm, S.W.; Frankel, S.L.; Goericke, R.; Olson, R.J.; Palenik, B.; Waterbury, J.B.; West-Johnsrud, L.; Zettler, E.R. Prochlorococcus marinas nov. gen. nov. sp. An oxyphototrophic marine prokaryote containing divinyl chlorophyll $a$ and chlorophyll b. Arch. Microbiol., 1992, 157, 297-300.

[5] Moore, L.R.; Rocap, G.; Chisholm, S.W. Physiology and molecular phylogeny of coexisting Prochlorococcus ecotypes. Nature, 1998, 393, 464-467.

[6] Moore, L.R.; Chisholm, S.W. Photophysiology of the marine cyanobacterium Prochlorococcus: Ecotypic differences among cultured isolates. Limnol. Oceanogr., 1999, 44, 628-638.

[7] Bazzaz, M.B.; Bradley, C.V.; Brereton, R.G. 4-vinyl-4-desethyl chlorophyll $a$ : Characterisation of a new naturally occurring chlorophyll using fast atom bombardment, field desorption and "in beam" electron impact mass spectrometry. Tetrahedron Letters 1982, 23, 1211-1214.

[8] Brereton, R.G.; Bazzaz, M.B. Positive and negative fast atom bombardment mass spectrometric studies on chlorophylls: Structure of 4-vinyl-4-desethyl chlorophyll $b$. 1983, 24, 5775-5778.

[9] Rodríguez, F.; Garrido, J.L.; Sobrino, C.; Johnsen, G.; Riobó, P.; Franco, J.; Aamot, I.; Ramilo, I.; Sanz, N.; Kremp, A. Divinyl chlorophyll $a$ in the marine eukaryotic protest Alexandrium ostenfeldii (Dinophyceae). Env. Microbiol., 2016, 18, 627-643.

[10] Airs, R.L.; Garrido, J.L. Liquid chromatography-mass spectrometry for pigment analysis. In: Phytoplankton pigments: Characterization, chemotaxonomy and applications in oceanography. Roy, S.; Llewellyn, C.A.; Egeland, E.S.; Johnsen, G. Eds.; Cambridge University Press: Cambridge, UK, 2011, pp. 314-342.

[11] Juin, C,; Bonnet, A,; Nicolau, E,; Bérard, J-B.; Devillers, R.; Thiéry, V.; Cadoret, J-P.; Picot, L. UPLC-MS ${ }^{\mathrm{E}}$ profiling of phytoplankton metabolites:Application to the identification of pigments and structural analysis of metabolites in Porphyridium purpureum. Mar. Drugs, 2015, 13, 2541-2558.

[12] Miyashita, H.; Adachi, K,; Kurano, N.; Ikemoto, H.; Chihara, M.; Miyachi, S. Chlorophyll $d$ as a major pigment. Nature, 1996, 338, 402 .
[13] Larkum, A.W.D.; Chen, M,; Li, Y.; Schliep, M.; Trampe, E.; West, J. A novel epiphytic chlorophyll $d$-containing cyanobacterium isolated from a mangrove-associated red alga. J. Phycol. 2012, 48, $1320-1327$.

[14] Murakami, A.; Miyashita, H.; Iseki, M.; Adachi, K.; Mimuro, M. Chlorophyll $d$ in an epiphytic cyanobacterium of red algae. Science, 2004, 303, 1633.

[15] Kühl, M.; Chen, M.; Ralph, P.J.; Schreiber, U.; Larkum, A.W.D. 2005. A niche for cyanobacteria containing chlorophyll $d$. Nature, 2005, 433, 820 .

[16] Miller, S.R.; Augustine, S.; Olson, T.L.; Blankenship, R.E.; Selker, J.; Wood, M. Discovery of a free-living chlorophyll $d$-producing cyanobacterium with a hybrid proteobacterial/cyanobacterial smallsubunit rRNA gene. Proc. Natl. Acad. Sci. USA, 2005, 102, 853.

[17] Fleming, E.D.; Prufert-Bebout, L. Characterization of cyanobacterial communities from high-elevation lakes in the Bolivian Andes. J. Geophys. Res.-Biogeosci., 2010, 115,

[18] Kashiyama, Y.; Miyashita, H,; Ohkubo, S.; Ogawa, N.O.; Chikaraishi, Y.; Takano, T.; Suga, H.; Toyofuku, T.; Nomaki, H.; Kitazato, H.; Nagata, T.; Ohkouchi, N. Evidence of global chlorophyll $d$. Science, 2008, 321, 658.

[19] McNamara, C.J.; Perry, T.D.; Bearce, K.A.; Hernandez-Duque, G.; Mitchell, R. Epilithic and endolithic bacterial communities in limestone from a Maya archaeological site. Microb. Ecol., 2006, 51, 51-64.

[20] de los Ríos, A.; Grube, M.; Sancho, L.G.; Ascaso, C. Ultrastructural and genetic characteristics of endolithic cyanobacterial biofilms colonizing Antarctic granite rocks. FEMS Microb. Ecol., 2007, 59, 386-395.

[21] Behrendt, L.; Larkum, A.W.D.; Anders, N.; Qvortrup, K.; Chen, M.; Ralph, P.; Sorensen, S.J.; Trampe, E.; Kuhl, M. Endolithic chlorophyll $d$-containing phototrophs. ISME J., 2011, 5, 10721076.

[22] Goh, F.; Allen, M.A.; Leuko, S.; Kawaguchi, T.; Decho, A.W. Burns, B.P.; Neilan, B.A. Determining the specific microbial populations and their spatial distribution within the stromatolite ecocsystem of Shark Bay. ISME J., 2009, 3, 383-396.

[23] Pickering, M.D.; Keely, B.J. Origins of enigmatic C-3 methyl and $\mathrm{C}-3 \mathrm{H}$ porphyrins in ancient sediments revealed from formation of pyrophaeophorbide $d$ in simulation experiments. Geochim. Cosmochim. Acta, 2013, 104, 111-122.

[24] Fukusumi, T.; Matsuda, K.; Mizoguchi, T; Miyatake, T.; Ito, S.; Ikeda, T.; Tamiaki, H.; Oba, T. FEBS Lett., 2012, 586, 2338-2341.

[25] Loughlin, P.C.; Willows, R.D.; Chen, M. In vitro conversion of vinyl to formyl groups in naturally occurring chlorophylls. Scientific Reports, 2014, 4, 1-9.

[26] Airs, R.L.; Keely, B.J. A novel approach for sensitivity enhancement in atmospheric pressure chemical ionization liquid chromatography/mass spectrometry of chlorophylls. Rapid Commun. Mass Spectrom., 2000, 14, 125-128.

[27] Airs, R.L.; Temperton, B.; Sambles, C.; Farnham, G.; Skill, S.C.; Llewellyn, C.A. Chlorophyll $f$ and chlorophyll $d$ are produced in the cyanobacterium Chlorogloeopsis fritschii when cultured under natural light and near-infrared radiation. FEBS Lett., 2014, 588, 3770-3777.

[28] Kobayashi, M.; Akutsu, S.; Fujinuma, D.; Furukawa, H.; Komatsu, H.; Hotota, Y.; Kato, Y.; Kuroiwa, Y.; Watanabe, T.; OhnishiKameyama, M.; Ono, H.; Ohkubo, S.; Miyashita, H. Physicochemical properties of chlorophylls in oxygenic photosynthesis - succession of co-factors from anoxygenic to oxygenic photosynthesis. In: Photosynthesis. Dubinsky, Z. Ed.; http://www.intechopen.com/books/photosynthesis, 2013, pp. 47-90.

[29] Pickering, M.D.; Keely, B.J. Low temperature abiotic formation of mesopyrophaeophorbide $a$ from pyrophaeophorbide $a$ under conditions simulating anoxic natural environments. Geochim. Cosmochim. Acta, 2011, 75, 533-540.

[30] Pickering, M.D. Low temperature sequestration of photosynthetic pigments: model studies and natural aquatic environments. $\mathrm{Ph} . \mathrm{D}$. thesis, University of York, 2009.

[31] Airs, R.L.; Keely, B.J. Atmospheric pressure chemical ionization liquid chromatography/mass spectrometry of bacteriochlorophylls from Chlorobiaceae: characteristic fragmentations. Rapid Commun. Mass Spectrom. 2002, 16, 453-461.

[32] Chen, M.; Schliep, M.; Willows, R.D.; Cai, Z-L.; Neilan, B.A.; Scheer, H. A red shifted chlorophyll. Science 2010, 329, 13181319.

[33] Gan, F.; Zhang, S.; Rockwell, N.C.; Martin, S.S.; Lagarias, J.C.; Bryant, D.A. Extensive remodeling of a cyanobacterial 
photosynthetic apparatus in far-red light. Science, 2014, 345, 13121316.

[34] Chen, M.; Li, Y.; Birch, D.; Willows, R.D. A cyanobacterium that contains chlorophyll $f$-a red-absorbing photopigment. FEBS Lett., 2012, 586, 3249-3254.

[35] Akutsu, S.; Fujinuma, D.; Furukawa, H.; Watanabe, T.; OhnishiKameyama, M.; Ono, H.; Ohkubo, S.; Miyashita, H.; Kobayashi, M. Pigment analysis of a chlorophyll $f$-containing cyanobacterium strain KC1 isolated from Lake Biwa. Photomed. Photobiol., 2011, 33, 35-40.

[36] Behrendt, L.; Brejnrod, A.; Schliep, M.; Sorensen, S.J.; Larkum, A.W.D.; Kühl, M. Chlorophyll $f$-driven photosynthesis in a cavernous cyanobacterium. ISME J., 2015, 9, 2108-2111

[37] Trampe, E.; Kühl, M. Chlorophyll $f$ distribution and dynamics in cyanobacterial beachrock biofilms. J. Phycol., 2016, 52, 990-996.

[38] Ho, M.Y.; Shen, G.Z.; Canniffe, D.P.; Zhao, C.; Bryant, D.A. Light-dependent chlorophyll $f$ synthase is a highly divergent paralog of PsbA of photosystem II. Science, 2016, 353, 886.

[39] Bryant, D.A.; Garcia Costas, A.M.; Maresca, J.A.; Chew, A.G.M.; Klatt, C.G.; Bateson, M.M.; Tallon, L.J.; Hostetler, J.; Nelson, W.C.; Heidelberg, J.F.; Ward, D.M. Candidatus Chloracidobacterium thermophilum: An aerobic phototrophic acidobacterium. Science, 2007, 317, 523-526.

[40] Imhoff, J.F. Phylogenetic taxonomy of the family Chlorobiaceae on the basis of 16S rRNA and fmo (Fenna Matthews-Olson protein) gene sequences. International Journal of Systematic and Evolutionary Microbiology, 2003, 53, 941-951.

[41] Bobe, F.W.; Pfennig, N.; Swanson, K.L.; Smith, K.M. Red shift of absorption maxima in Chlorobiineae through enzymic methylation of their antenna bacteriochlorophylls. Biochem., 1990, 29, 43404348.

[42] Borrego, C.M.; Garcia-Gil, L.J. Rearrangement of light harvesting bacteriochlorophyll homologues as a response of green Sulphur bacteria to low light intensities. Photosynth. Res., 1995, 45, 21-30.

[43] Caple, M.B.; Chow, H.; Strouse, C.E. Photosynthetic pigments of green Sulphur bacteria: The esterifying alcohols of bacteriochlorophylls $c$ from Chlorobium limicola. J. Biol. Chem., 1978, 253, 6730-6737.

[44] Repeta, D.J.; Simpson, D.J; Jorgensen, B.B.; Jannasch, H.W. Evidence for anoxygenic photosynthesis from the distribution of bacteriochlorophylls in the Black Sea. Nature, 1989, 342, 69-72.

[45] Otte, S.C.M.; Jan van de Meent, E.; van Veelen, P.A.; Pundsnes, A.S.; Amesz, J. Identification of the major chlorosomal bacteriochlorophylls of the green sulfur bacteria Chlorobium vibrioforme and Chlorobium phaeovibrioides: their function in lateral energy transfer. Photosynth. Res., 1993, 35, 159-169.

[46] Airs, R.L.; Borrego, C.M.; Garcia-Gil, J.; Keely, B.J. Identification of the bacteriochlorophyll homologues of Chlorobium phaeobacteroides strain UdG6053 grown at low light intensity. Photosynth. Res., 2001, 70, 221-230.

[47] Airs, R.L.; Keely, B.J. A high resolution study of the chlorophyll and bacteriochlorophyll pigment distributions in a calcite/gypsum microbial mat. Org. Geochem., 2003, 34, 539-551.

[48] Glaeser, J.; Bañeras, L.; Rütters, H.; Overmann, J. Novel bacteriochlorophyll $e$ structures and species-specific variability of pigment composition in green sulfur bacteria. Arch. Microbiol., 2002, 177, 475-485.

[49] Massé, A.; Airs, R.L.; Keely, B.J.; de Wit, R. The impact of different intensities of green light on the bacteriochlorophyll homologue composition of the chlorobiaceae Prosthecochloris aestuarii and Chlorobium phaeobacteroides. Microbiol.-SGM, 2004, 150, 2555-2564.

[50] Pfennig, N. Green sulphur bacteria. In: Bergeys Manual of Systematic Bacteriology, Murray, R.G.; Brenner, D.J.; Bryant, M.P.; Hol, J.G.; Krieg, N.R.; Moulder, J.W.; Pfennig, N.; Sneath, P.H.; Staley, J.T.; Williams, S.T. Eds.; Williams and Wilkins, Baltimore, 1989, pp. 1682-1709.

[51] Pierson, B.K.; Castenholz, R.W. Taxonomy and physiology of filamentous anoxygenic phototrophs. In: Anoxygenic photosynthetic bacteria, Advances in Photosynthesis, Blankenship, R.E.; Madigan, M.T.; Bauer, C.E. Eds.; Kluwer Academic Publishers, Dordrecht, 1995; Vol II, pp. 31-47.

[52] Gich, F.; Airs, R.L.; Danielsen, M.; Keely, B.J.; Abella, C.A.; Garcia-Gil, J.; Miller, M.; Borrego, C.M. Characterization of the chlorosome antenna of the filamentous anoxygenic phototrophic bacterium Chloronema sp. Strain UdG9001, Arch. Microbiol., 2003, 180, 417-426.
Mizoguchi, T.; Harada, J.; Tamiaki, H. Characterization of chlorophyll pigments in the mutant lacking 8-vinyl reductase of green photosynthetic bacterium Chlorobaculum tepidum, Bioorganic and Medicinal Chemistry, 2012, 20, 6803-6810.

[54] Mizoguchi, T.; Harada, J.; Tsukatani, Y.; Tamiaki, H. Isolation and characterization of a new bacteriochlorophyll-c bearing a neopentyl substituent at the 8-position from the bciD-deletion mutant of the brown-colored green sulfur bacterium Chlorobaculum limnaeum. Photosynth. Res., 2014, 121, 3-12.

[55] Chillier, X.F.D.; Van Berkel, G.J.; Gulacar, F.O.; Buchs, A. Characterisation of chlorins within a natural chlorin mixture using electrospray/ion trap mass spectroscopy. Org. Mass Spectrom. 1994, 29, 672-678.

[56] Wilson, M.A.; Hodgson, D.A.; Keely, B.J. Atmospheric pressure chemical ionization liquid chromatography/multistage mass spectrometry for assignment of sedimentary bacteriochlorophyll derivatives. Rapid Commun. Mass Spectrom., 2005, 19, 38-46.

[57] Squier, A.H.; Hodgson, D.A.; Keely, B.J. Sedimentary pigments as markers for environmental change in an Antarctic lake. Org. Geochem., 2002, 33, 1655-1665.

[58] Garcia Costas, A.M.; Tsukatani, Y.; Rijpstra, W.I.C.; Schouten, S.; Welander, P.V.; Summons, R.E.; Bryant, D.A. Identification of the bacteriochlorophylls, carotenoids, quinones, lipids and hopanoids of "Candidatus Chloracidobacterium thermophilum". J. Bacteriol., 2012, 194, 1158-1168.

[59] Squier, A.H.; Hodgson, D.H.; Keely, B.J. Identification of bacteriophaeophytin $a$ esterified with geranylgerniol in an Antarctic lake sediment. Org. Geochem., 2004, 35, 203-207.

[60] Mizoguchi, T.; Saga, Y.; Tamiaki, H. Isolation and structure determination of a complete set of bacteriochlorophyll- $d$ homologs and epimers from a green sulfur bacterium Chlorobium vibrioforme and their aggregation properties in hydrophobic solvents. Photochem. Photobiol. Sci., 2002, 1, 780-787.

[61] Rosell-Mele, A.; Carter, J.F.; Maxwell, J.R. Liquid chromatography / tandem mass spectrometry of free base alkyl porphyrins for the characterization of the macrocyclic substituents in components of complex mixtures. Rapid Commun. Mass Spectrom., 1999, 13, 568-573.

[62] Wilson, M.A.; Hodgson, D.A.; Keely, B.J. Structural variations in derivatives of the bacteriochlorophylls of Chlorobiaceae: impact of stratigraphic resolution on depth profiles as revealed by methanolysis. Org. Geochem., 2004, 35, 1299-1307.

[63] Wilson, M.A.; Siti, R.; Saleh, M.; Hodgson, D.A.; Keely, B.J. Atmospheric pressure chemical ionization liquid chromatography/multistage mass spectrometry of isobaric bacteriophaeophorbide $d$ methyl esters. Rapid Commun. Mass Spectrom. 2003, 17, 2455-2458.

[64] Katz, J.J.; Strain, H.H.; Svec, W.A.; Studier, M.H.; Janson, T.R.; Cope, B.T.; Harkness, A.L. Esterifying alcohols in chlorophylls of purple photosynthetic bacteria - new chlorophyll, bacteriochlorophyll (GG), all-trans-geranylgeranyl bacteriochlorophyllide a. J. Am. Chem. Soc., 1972, 94, 7938.

[65] Wakao, N.; Yokoi, N.; Isoyama, N.; Hirashi, A.; Shimada, K.; Kobayashi, M.; Kise, H.; Iwaki, M.; Itoh, S.; Takaichi, S.; Sakurai, Y. Discovery of natural photosynthesis using Zn-containing bacteriochlorophyll in an aerobic bacterium Acidiphilium rubrum. Plant Cell Physiol. 1996, 37, 889-893.

[66] Kobayashi, M.; Yamamura, M.; Akiyama, M.; Kise, H.; Inoue, K.; Hara, M.; Wakao, N.; Yahara, K.; Watanabe, T. Acid resistance of Zn-bacteriochlorophyll a from an acidophilic bacterium Acidiphilium rubrum. Analytical Sciences, 1998, 14, 1149-1152.

[67] Zeng, Y.; Feng, F.; Medová, H.; Dean, J.; Koblížek, M. Functional type 2 photosynthetic reaction centers found in the rare bacterial phylum Gemmatimonadetes. Proc. Natl. Acad. Sci. USA, 2014 111, 7795-7800.

[68] Yurkov, V.V.; Beatty, J.T. Aerobic anoxygenic phototrophic bacteria. Microbiol. Mol. Biol. Rev., 1998, 62, 695-724.

[69] Kolber, Z.S.; Van Dover, C.L.; Niederman, R.A.; Falkowski, P.G. Bacterial photosynthesis in surface waters of the open ocean. Nature, 2000, 407, 177-179.

[70] Kolber, Z.S.; Plumley, F.G.; Lang, A.S.; Beatty, J.T.; Blankenship, R.E.; VanDover, C.L.; Vetriani, C.; Koblizek, M.; Rathgeber, C.; Falkowski, P.G. Contribution of aerobic photoheterotrophic bacteria to the carbon cycle in the ocean. Science, 2001, 292, 24922492.

[71] Béjà, O.; Suzuki, M.T.; Heidelberg, J.F.; Nelson, W.C.; Preston, C.M.; Hamada, T.; Elsen, J.A.; Fraser, C.M.; DeLong, E.F. 
Unexpected diversity among marine aerobic anoxygenic phototrophs. Nature, 2002, 415, 630-633.

[72] Cottrell, C.T.; Mannino, A.; Kirchman, D.L. Aerobic anoxygenic phototrophic bacteria in the mid-Atlantic bight and the north Pacific gyre. Appl. Environ. Microbiol., 2006, 72, 557-564.

[73] Gest, H.; Favinger, J.L. Heliobacterium-chlorum, an anoxygenic brownish-green photosynthetic bacterium containing a new form of bacteriochlorophyll. Archives of Microbiology, 1983, 136, 11-16.
[74] Brockman, H.; Lipinski, A. Bacteriochlorophyll g. A new bacteriochlorophyll from Heliobacterium chlorum. Arch. Microbiol., 1983, 136, 17-19.

[75] Michalski, T.J.; Hunt, J.E.; Bowman, M.K.; Smith, U.; Bardeen, K.; Gest, H.; Norris, J.R.; Katz, J.J. Bacteriopheophytin $g$ : Properties and some speculations on a possible primary role for bacteriochlorophylls $b$ and $g$ in the biosynthesis of chlorophylls. Proc. Natl. Acad. Sci. USA, 1987, 84, 2570-2574. 